\title{
Characterization and Treatment of Textile Wastewater by Aquatic Plants (Macrophytes) and Algae
}

\author{
Chapol Kumar Roy ${ }^{1}$, Miskat Ara Akhter Jahan ${ }^{1}$, Shafkat Shamim Rahman 2* \\ ${ }^{1}$ Bangladesh Council of Scientific and Industrial Research (BCSIR), Dhaka-1205, BANGLADESH \\ ${ }^{2}$ United Surgical (BD) Ltd, Gazipur-1702, BANGLADESH
}

*Corresponding Author: shafkatshamimrahman@gmail.com

Citation: Roy, C. K., Jahan, M. A. A. and Rahman, S. S. (2018). Characterization and Treatment of Textile Wastewater by Aquatic Plants (Macrophytes) and Algae. European Journal of Sustainable Development Research, 2(3), 29. https://doi.org/10.20897/ejosdr/85933

Published: July 9, 2018

\begin{abstract}
Textile wastewater contains large quantities of organic and inorganic compounds, which cause toxic and hazardous pollutants in the environment. Efficacy, efficiency and feasibility of the biological treatment method using macrophytes and algae were investigated, and various physicochemical parameters (TSS, TDS, $\mathrm{pH}$, color, EC, DO, BOD, COD and metal concentration) were also analyzed. In pre-treated sample, TSS, TDS, pH, temperature, DO, BOD, COD, EC and color were recorded as $913 \mathrm{mg} / \mathrm{L}, 2250 \mathrm{mg} / \mathrm{L}, 9.4,41^{\circ} \mathrm{C}$, $2.84 \mathrm{mg} / \mathrm{L}, 358 \mathrm{mg} / \mathrm{L}, 721 \mathrm{mg} / \mathrm{L}, 1555 \mu \mathrm{S} / \mathrm{cm}$ and $1347 \mathrm{TCU}$ respectively. As, $\mathrm{Cr}, \mathrm{Pb}$ and $\mathrm{Cu}$ (heavy metals) were observed exceeding the limit stipulated by WHO. COD and the $\mathrm{pH}$ reduction was effective in biological treatment with aquatic plants, algae and their combination, but not significant for color removal. Eichbornia treatment found most effective in reducing BOD, COD, TDS and TSS. Mixed treatment reduced the $\mathrm{pH}$ from 9.4 to 7.5. Both macrophytes and algae exhibited appreciable heavy metal uptake tendency, but Eichhornia crassipes was identified as the most effective in heavy metal removal because of its extensive root system. An Eichbornia based adsorbent was prepared for removal of color from the wastewater and found to be capable of removing 58\% of the color. The investigation erected pathway towards phytoremediation of polluted surface water in lakes and rivers, too.
\end{abstract}

Keywords: textile effluents, phytoremediation, aquatic macrophytes, algae

\section{INTRODUCTION}

Textile is one of the largest and vital industrial sectors of Bangladesh with regard to earn foreign exchange and to engender employment. More than $78 \%$ of the total export earning comes from textile and textile-related goods. This sector provides 4.5 million jobs of which $80 \%$ are women and contributes $13 \%$ to national GDP (Bangladesh Textile Mills Association, 2007).

In Bangladesh, textile industries sector produces a huge amount of sewage which is highly noxious for the environment. In the finishing courses, a considerable amount of wastewater is generated. The industries consume large capacity of water and chemical for wet processes. The quantities of effluent discharged vary from plant to plant depending on the water consumption and the average daily products (Sultana et al., 2009). Textile discharge is disreputably known to contain strong color, a substantial number of suspended solids, an exceedingly fluctuating $\mathrm{pH}$, a high temperature, COD, BOD and so on (Gurnham, 1965). As a result of these pernicious attributes, wastewater treatment is a basic necessity before disposing to natural water framework (Kabir et al., 2002). The process of changing raw fibers into completed apparel and non-apparel textile goods is exceptionally complex, 
where most textile plants employ strategies which are not eco-friendly (Hashem et al., 2005). $\mathrm{ZnCl}_{2}$ utilization is an option method leads to the fabric weight increment and in dye uptake and permits easy recovery of $\mathrm{NaOH}$. In addition, the procedure is eco-friendly and does not require neutralization by acetic or formic acid (Karim et al., 2006). In recent years, hypochlorite is being supplanted by other bleaching operators. An ecologically safe alternative to hypochlorite is peracetic acid. It breaks downs to biodegradable oxygen and acetic acid. One of the upsides of peracetic acid is higher brightness value with less fiber loss (Rott and Minke, 1999). Recently, a one-step preliminary process for de-sizing, scouring, and bleaching has lessened the volume of water. The plausibility of a one-step process for de-sizing, scouring, bleaching, and mercerizing of cotton fabric followed by dyeing with direct dyes has been discussed (Slokar and Majcen, 1997). The color arises from chromophore and auxochrome groups in the dyes, which also cause pollution (Azymezyk et al., 2007). The first reported concept of total eco-friendly mordents or natural mordents during dyeing with natural dyes (Padma et al., 2008), were the first to point out that natural dye shades could be developed by a multiple dip method that renders natural dyeing more economical (Deo and Desai, 1999). Dyeing of natural and synthetic fibers with natural dyes has been the subject of numerous investigations. Extension of eco-friendly non-formaldehyde dye fixative agents for reactive dyes was recently reported (Bechtold et al., 2005; Sekar et al., 1995).

On the other hand, biological treatment could achieve greater efficiencies in the decolorization and detoxification of textile wastewater by using native aquatic plants. So, the objectives of the present study were to characterize the textile effluent and to find out an economically and environmental (eco) friendly solution for reducing the toxic effects of textile effluent using aquatic macrophytes and algae (Westhead et al., 2004).

\section{MATERIALS AND METHODS}

\section{Collection and Analysis of Effluent Samples}

The Abed Textiles Processing Mills Limited at Ghoradia in Narsingdi Sadar, is one of the pioneers of composite textile products in Bangladesh, which process fabrics for print, finish and package products to garments. Sample wastewater was collected from a common central drainage line of the industry where effluents were deposited from all the functional operations. Sampling protocol was followed carefully to inhibit the intrusion of any foreign particles that may affect the results. Sample color was measured by a colorimeter (Hanna: HI93727). The temperature was measured at the time of sample collection and total suspended solids (TSS), total dissolved solids (TDS), dissolved oxygen (DO), electrical conductivity (EC) and salinity was determined by standard equipment (Tufekci et al., 1998). Biological oxygen demand (BOD) and chemical oxygen demand (COD) were determined by 5-day BOD test and closed reflux, titrimetric method, respectively (APHA, 1998). Heavy metals were measured by atomic absorption spectroscopy (Shimadzu, Model-AA6401F AAS).

\section{Collection of Aquatic Macrophytes and Algae}

Aquatic macrophytes were collected from the Jahangirnagar University campus lakes and preserved in the artificial pond in Biological Research Division of Bangladesh Council of Scientific and Industrial Research (BCSIR) using tap water at normal temperature and without any nutrient. The inoculum of Nostoc was provided by the Biological Research Division.

\section{Methods for Toxicity Testing}

The collected effluent sample was taken in a big plastic bowl and settled for three days. After the settlement, the effluent was taken for toxicity testing. The experiments were designed in three sets. In $1^{\text {st }}$ and $2^{\text {nd }}$ sets, each earthen vessel with a dimension of $16^{\prime \prime}$ diameter $\times 10^{\prime \prime}$ depth containing four liters of effluent and $3^{\text {rd }}$ set with $30^{\prime \prime}$ diameter $\times 20$ " depth vessel containing ten liters of effluent were used. Before starting experiment every vessel was washed properly followed by rinsing with effluent. Each treatment had 3 replicas and repeated twice.

\section{Treatment with Macrophytes}

The $1^{\text {st }}$ set of experiment was conducted with three types of aquatic macrophytes, Spirodela polyrbiza, Pistia stratiotes, Eichhornia crassipes and one algae (Nostoc), taken individually in a separate vessel. The body and root part of the plants were washed to remove sediments and other impurities. Six fresh plants of weight 200-250 gm Pistia stratiotes and 50 gm of Spirodela polyrbiza (Tiwari et al., 2007), and three fresh Eichbornia crassipes plants of weight 400-450 gm were separately used for toxicity test. To evaluate the toxic effect of tannery effluents, $50 \mathrm{gm}$ of fresh algae (Nostoc) were taken into a separate earthen vessel. The effluent was shaken by a stick at two to three hours' interval to maintain the equal distribution of algae. In this investigation, 4 cycles of plants were used. The first and second cycle lasted for a day, the third cycle for two days and the last cycle had been continued for three days. 


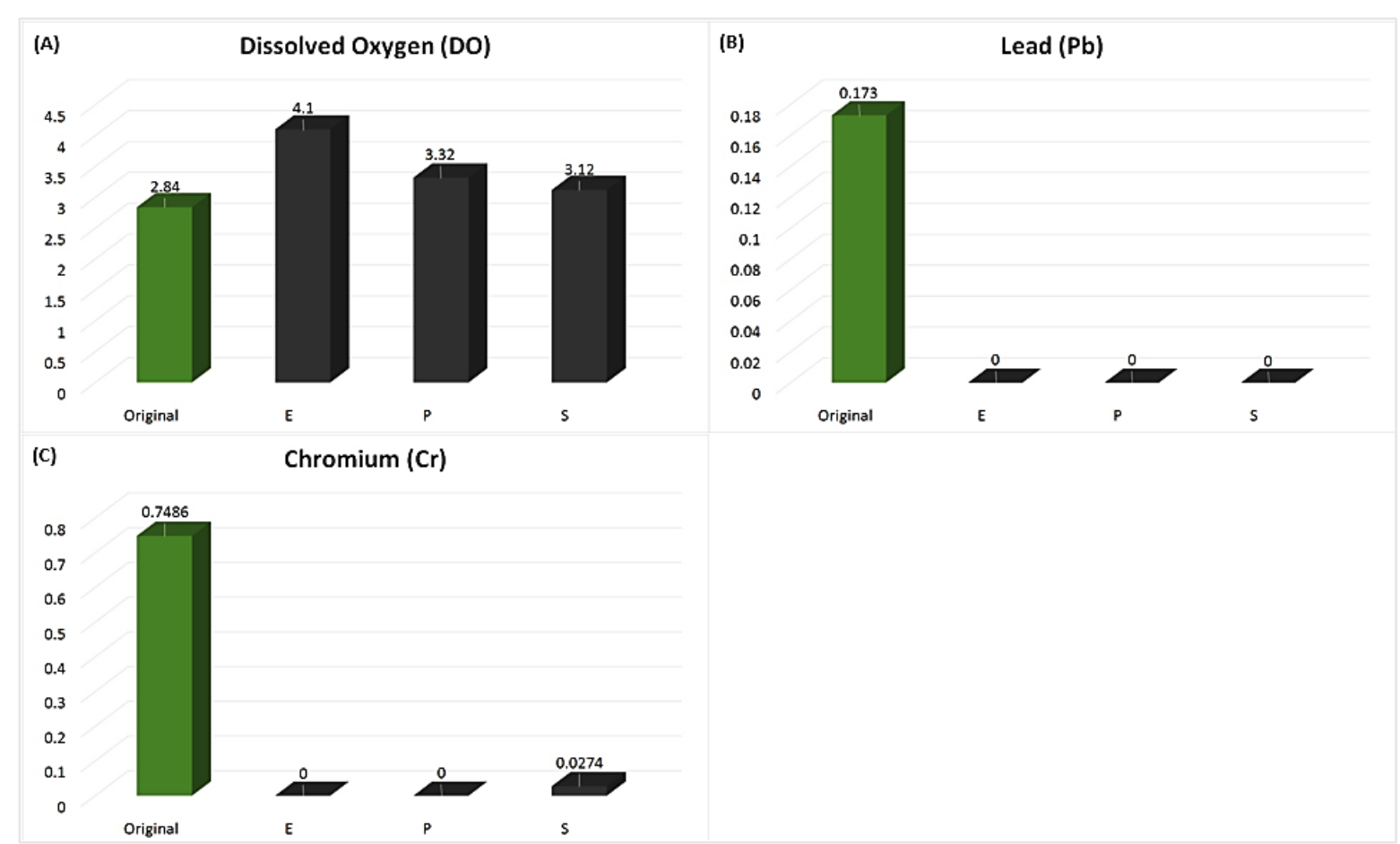

Figure 1. Effect of Eichhornia, Pistia and Spirodela on three important parameters, (A) DO increase, (B) Pb and (C) Cr reduction, on wastewater

After every cycle, the plants were replaced with fresh plants. Thus, the effluent was kept in exposure to the plants for a total period of seven days.

\section{Combined Treatment with Aquatic Macrophytes and Algae}

In the $2^{\text {nd }}$ set of experiment, 3 types of aquatic macrophytes were used separately in combination with algae. Two fresh Eichhornia crassipes $+25 \mathrm{gm}$ of Nostoc, 3 fresh Pistia stratiotes $+25 \mathrm{gm}$ of Nostoc and $50 \mathrm{gm}$ of Spirodela polyrbiza +25 gm of Nostoc were taken to the treatment vessels.

\section{Mixed Treatment}

In the $3^{\text {rd }}$ set of experiment, 3 types of aquatic macrophytes, 2 fresh Eichhornia crassipes plants, 3 fresh Pistia stratiotes plants, $50 \mathrm{gm}$ of fresh Spirodela polyrbiza plants were taken along with $25 \mathrm{gm}$ of Nostoc, algae in the same treatment vessel. 4 cycles of plants were used.

\section{RESULTS}

In the present study, attempts were made to treat the effluent in a biological way which was more environmentfriendly, cheap and easy.

\section{Analysis of the Textile Wastewater Characteristics}

Physicochemical data of the textile wastewater and permissible limits for parameters in the wastewater from an industrial establishment by World Health Organization (WHO) (WHO, 2002) were presented in Table 2. Among the parameters, TDS and TSS were found $2250 \mathrm{mg} / \mathrm{L}$ and $913 \mathrm{mg} / \mathrm{L}$ respectively, $\mathrm{pH}$ and temperature of the wastewater were recorded to be 9.4 and $41^{\circ} \mathrm{C}$. DO was found $2.84 \mathrm{mg} / \mathrm{L}$. COD, BOD and EC were found as 721 $\mathrm{mg} / \mathrm{L}, 358 \mathrm{mg} / \mathrm{L}$ and $1555 \mu \mathrm{S} / \mathrm{cm}$ respectively. Water anions as phosphate, sulfate and chloride were found as $1.21 \mathrm{mg} / \mathrm{L}, 207.6 \mathrm{mg} / \mathrm{L}$ and $0.006 \mathrm{mg} / \mathrm{L}$ respectively, which were within the permissible limit. Metals as $\mathrm{Na}$ and $\mathrm{K}$ were tested in the sample and were detected within the permissible limit. However, heavy metals as $\mathrm{Cr}, \mathrm{Cu}, \mathrm{Pb}$ and As were observed way beyond the permissible limit. Effects of different macrophytes and algae on different parameters of effluents were presented in Table 2.

\section{Effect on Effluent's DO Level}

After P, E, N and S treatments, DO levels in the effluent were changed to 3.32, 4.1, 1.38 and $3.12 \mathrm{mg} / \mathrm{L}$ respectively. DO levels in the effluent after the combined treatment of EN, PN and SN were 3.08, 2.75 and 2.34 $\mathrm{mg} / \mathrm{L}$ respectively. In the mixed treatment DO level of effluent was $1.7 \mathrm{mg} / \mathrm{L}$. Maximum $44 \%$ increase in DO 
Table 1. Comparison of the concentrations of heavy metals in fresh and spent plants

\begin{tabular}{lcccccc}
\hline Heavy metal $(\mathrm{ppm})$ & \multicolumn{2}{c}{ Eichhornia } & \multicolumn{2}{c}{ Pistia } & \multicolumn{2}{c}{ Spirodela } \\
\cline { 2 - 7 } & Fresh & Spent & Fresh & Spent & Fresh & Spent \\
\hline $\mathrm{Cr}$ & 0 & 1.9087 & 0 & 1.2268 & 0.0314 & 0.8504 \\
\hline $\mathrm{Pb}$ & 0.3106 & 0.3478 & 0.0628 & 0.1908 & 0.0297 & 0.2569 \\
\hline $\mathrm{Fe}$ & 15.2776 & 16.7189 & 12.2450 & 15.2992 & 4.6713 & 6.6274 \\
\hline $\mathrm{Cu}$ & 0.2980 & 0.4486 & 0.1531 & 0.9546 & 0.1684 & 0.4037 \\
\hline $\mathrm{Zn}$ & 1.6559 & 1.6865 & 1.6215 & 1.8184 & 1.579 & 1.6702 \\
\hline $\mathrm{As}$ & 0 & 0.0912 & 0 & 0.0736 & 0 & 0.0484 \\
\hline
\end{tabular}

Table 2. Effect of different biological treatments on wastewater

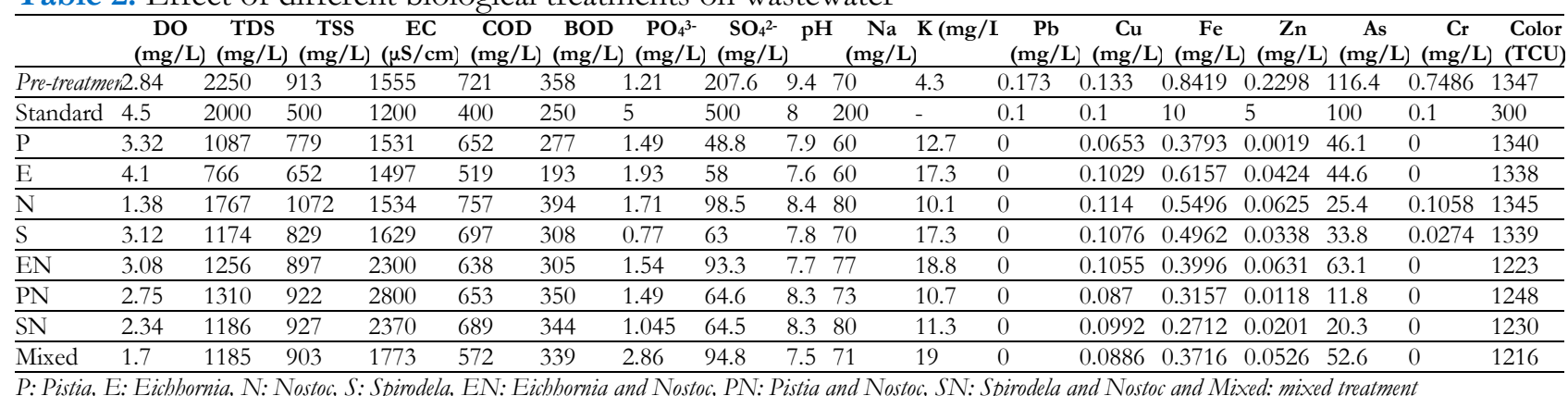

level was affected by Eichhornia $(4.1 \mathrm{mg} / \mathrm{L})$ on the seventh day (Table 2; Figure 1) which is slightly incorporated with previous findings (Gidhamaari et al., 2012).

\section{Effect on Effluent's TDS Level}

After P, E, N and S treatments, TDS levels in the effluent were changed to 1087, 766, 1767 and $1174 \mathrm{mg} / \mathrm{L}$ respectively. TDS levels in the effluent after the combined treatment of EN, PN and SN were 1256, 1310 and $1186 \mathrm{mg} / \mathrm{L}$ respectively. TDS level of mixed treatment effluent was $1185 \mathrm{mg} / \mathrm{L}$. The maximum decrease in TDS level was affected by Eichbornia treatment (Table 2).

\section{Effects on Effluent's TSS Level}

After P, E, N and S treatments, TSS levels in the effluent were found as 779, 652, 1072 and $829 \mathrm{mg} / \mathrm{L}$ respectively. TSS levels in the effluent after the combined treatment of EN, PN and SN were 897, 922, and 927 $\mathrm{mg} / \mathrm{L}$ respectively. In the mixed treatment, TSS level of effluent was $903 \mathrm{mg} / \mathrm{L}$. The maximum decrease in the TSS level was affected by Eichbornia treatment (Table 2).

\section{Effects on Effluent's EC}

High EC indicated that a large number of ionic substances like sodium, potassium, iron etc. were present in textile effluent (Kabir et al., 2002). After P, E, N and S treatments, EC in the effluent were detected in 1531, 1497, 1534 and $1629 \mu \mathrm{S} / \mathrm{cm}$ respectively. EC in the effluent after the combined treatment of EN, PN and SN were 2300, $2800,2370 \mu \mathrm{S} / \mathrm{cm}$ and mixed treatment was $1773 \mu \mathrm{S} / \mathrm{cm}$ respectively. The maximum decrease in the EC level was affected by Eichbornia treatment (Table 2).

\section{Effects on Effluent's COD}

After P, E, N and S treatments, COD in the effluent were found 652, 519, 757 and $697 \mathrm{mg} / \mathrm{L}$ respectively. COD in the combined treatment of EN, PN and SN were $638,653,689 \mathrm{mg} / \mathrm{L}$ and mixed treatment was $572 \mathrm{mg} / \mathrm{L}$ respectively. Maximum 28\% decrease in the COD was affected by Eichhornia treatment (Table 2). The COD improvement rate with microflora (biological method) was 69\% (Rajvaiday and Markendey, 1998).

\section{Effects on Effluent's BOD}

P, E, N and S treatments changed the BOD in the effluent to 277, 193, 394 and $308 \mathrm{mg} / \mathrm{L}$ respectively. BOD in the effluent after the combined treatment of EN, PN and SN were 305, 350 and $344 \mathrm{mg} / \mathrm{L}$ respectively. Mixed treatment changed the BOD to $339 \mathrm{mg} / \mathrm{L}$. Maximum 46\% decrease in the BOD was affected by Eichbornia treatment (Table 2) whereas (Gidhamaari et al., 2012 ) the previous report was the bacterial culture improved BOD almost $75 \%$ within two weeks from the date of inoculation.

\section{Effects on Effluent's $\mathrm{PO}_{4}{ }^{3-}, \mathrm{SO}_{4}{ }^{2-}$ and $\mathrm{Cl}^{-} \mathrm{Level}$}

Phosphate level was within the standard limit in the wastewater sample $(1.21 \mathrm{mg} / \mathrm{L})$. After P, E, N and S treatments, the levels in the effluent were recorded as $1.49,1.93,1.71$ and $0.77 \mathrm{mg} / \mathrm{L}$ respectively. And after the 
combined treatment of EN, PN, SN and after mixed treatment were 1.54, 1.49, 1.045 and $2.86 \mathrm{mg} / \mathrm{L}$ respectively. The maximum decrease in the $\mathrm{PO}_{4}{ }^{3-}$ level was caused by Spirodela treatment in the present study (Table 2) where others (Sekaran and Mariappan, 1994) reported the efficiency of removal of phosphates was greater in the immobilized condition than free cells of bacteria. Sulfate level was within the standard limit in the wastewater sample (207.6 mg/L) (Table 2). After P, E, N and S treatments, levels observed as 48.8, 58, 98.5 and $63 \mathrm{mg} / \mathrm{L}$ respectively. After the combined treatment of EN, PN and $\mathrm{SN}$ the levels were 93.3, 64.6 and $64.5 \mathrm{mg} / \mathrm{L}$ respectively. Mixed treatment changed the sulfate level to $94.8 \mathrm{mg} / \mathrm{L}$. Maximum decrease was observed by Pistia treatment. After P, E, N and S treatments, chloride levels in the effluent were found 0.006, 0.02, 0.01 and 0.006 $\mathrm{mg} / \mathrm{L}$ respectively. After the combined treatment of EN, PN and SN the levels were 0.018, 0.01 and $0.008 \mathrm{mg} / \mathrm{L}$ respectively. Mixed treatment changed the level to $0.02 \mathrm{mg} / \mathrm{L}$. Data were not included in the table because chloride level was within the standard limit in the wastewater sample $(0.006 \mathrm{mg} / \mathrm{L})$.

\section{Effects on Effluent's pH}

Initial $\mathrm{pH}$ was found above the standard (6.5 - 8) (Table 2). $\mathrm{Na}_{2} \mathrm{CO}_{3}, \mathrm{NaHCO}_{3}$ and $\mathrm{NaOH}$ used in the dye and printing process may be responsible for the high $\mathrm{pH}$ of the effluent (Ahmed, 2007). After $\mathrm{P}, \mathrm{E}, \mathrm{N}$ and $\mathrm{S}$ treatments, $\mathrm{pH}$ values of the effluent were detected as 7.9, 7.6, 8.4 and 7.8 respectively. After the combined treatment of EN, $\mathrm{PN}$ and $\mathrm{SN}$ the values were 7.7, 8.3 and 8.3 respectively. Mixed treatment changed to a maximum decrease of 7.5.

\section{Effects on Effluent's $\mathrm{Na}$ and K Level}

After P, E, N and S treatments, Na levels of the effluent were found $60,60,80$ and $70 \mathrm{mg} / \mathrm{L}$ respectively. $\mathrm{Na}$ levels in the effluent after the combined treatment of EN, PN and SN were 77, 73, $80 \mathrm{mg} / \mathrm{L}$ and mixed treatment was $71 \mathrm{mg} / \mathrm{L}$ respectively. The maximum decrease in the $\mathrm{Na}$ level was affected by Pistia and Eichhornia treatment. From Table 2, it was found that the wastewater sample contained $4.3 \mathrm{mg} / \mathrm{L}$ of potassium. After P, E, N and S treatments, $\mathrm{K}$ levels of the effluent were found as 12.7, 17.3, 10.1 and $17.3 \mathrm{mg} / \mathrm{L}$ respectively. $\mathrm{K}$ levels in the effluent after the combined treatment of EN, PN and SN were 18.8, 10.7 and $11.3 \mathrm{mg} / \mathrm{L}$ respectively. $\mathrm{K}$ level of effluent was $19 \mathrm{mg} / \mathrm{L}$ in mixed treatment. The maximum decrease in the K level was affected by Nostoc treatment.

\section{Effects on Effluent's Cd Level}

No Cd was found in the original sample. After all treatments, Cd levels of the effluent were also found nil, data was not shown.

\section{Effects on Effluent's Pb Conc.}

$\mathrm{Pb}$ level was beyond the standard limit in the wastewater sample $(0.173 \mathrm{mg} / \mathrm{L})$. All treatments showed $0 \mathrm{mg} / \mathrm{L}$ $\mathrm{Pb}$ level of effluent. So, all the treatments were very effective in removal of $\mathrm{Pb}$ (Table 2; Figure 1).

\section{Effects on Effluent's Cu Conc.}

Table 2, indicated the $\mathrm{Cu}$ level which was beyond the standard limit in the wastewater sample $(0.133 \mathrm{mg} / \mathrm{L})$. After P, E, N and S treatments, Cu levels of the effluent were $0.0653,0.1029,0.114$ and $0.1076 \mathrm{mg} / \mathrm{L}$ respectively. The Cu levels in the effluent after the combined treatment of EN, PN and SN were also 0.1055, 0.087 and 0.0992 $\mathrm{mg} / \mathrm{L}$ respectively. Mixed treatment also changed the $\mathrm{Cu}$ level of effluent to $0.0886 \mathrm{mg} / \mathrm{L}$. The maximum decrease in the $\mathrm{Cu}$ level was affected by Pistia treatment.

\section{Effects on Effluent's Fe Conc.}

Fe level was within the standard limit in the wastewater sample Table $2(0.8419 \mathrm{mg} / \mathrm{L})$. After $\mathrm{P}, \mathrm{E}, \mathrm{N}$ and $\mathrm{S}$ treatments, Fe levels of the effluent were found $0.3793,0.6157,0.5496$ and $0.4962 \mathrm{mg} / \mathrm{L}$ respectively. After combined treatment, Fe levels of EN, PN and SN were $0.3996,0.3157$ and $0.2712 \mathrm{mg} / \mathrm{L}$ respectively. Mixed treatment showed $0.3716 \mathrm{mg} / \mathrm{L}$ of Fe level. The maximum decrease in the Fe level was found in the combined treatment of (Spirodela + Nostoc).

\section{Effects on Effluent's Zn Conc.}

The $\mathrm{Zn}$ level was within the standard limit in the wastewater sample Table $2(0.2298 \mathrm{mg} / \mathrm{L})$. Treatment of $\mathrm{P}$, $\mathrm{E}, \mathrm{N}$ and $\mathrm{S}$ showed that the $\mathrm{Zn}$ levels of the effluent were $0.0019,0.0424,0.0625$ and $0.0338 \mathrm{mg} / \mathrm{L}$ respectively. $\mathrm{Zn}$ levels in the effluent after the combined treatment of EN, PN and SN were 0.0631, 0.0118 and $0.0201 \mathrm{mg} / \mathrm{L}$ respectively. Mixed treatment changed the $\mathrm{Zn}$ level of effluent to $0.0526 \mathrm{mg} / \mathrm{L}$. The maximum decrease in the $\mathrm{Zn}$ level was affected by Pistia treatment.

\section{Effects on Effluent's As Conc.}

It was observed from Table 2 that the As level was beyond the standard limit in the wastewater sample (116.4 $\mathrm{mg} / \mathrm{L}$ ). After P, E, N and S treatments, As levels of the effluent were found 46.1, 44.6, 25.4 and $62.2 \mathrm{mg} / \mathrm{L}$ 
respectively. As levels in the effluent after the combined treatment of EN, PN and SN were 72.5, 56.7 and 75.6 $\mathrm{mg} / \mathrm{L}$ and mixed treatment was $43.3 \mathrm{mg} / \mathrm{L}$ respectively. All treatment decreased the As level but the maximum decrease was observed in the combined treatment of (Pistia + Nostoc).

\section{Effects on Effluent's Cr Conc.}

Table 2 and Figure 1, indicated the $\mathrm{Cr}$ level which was beyond the standard limit in the wastewater sample $(0.7486 \mathrm{mg} / \mathrm{L})$. Cr levels of the effluent after treatment of P, E, N and S, were found 0, 0, 0.1058 and $0.0274 \mathrm{mg} / \mathrm{L}$ and treatment of EN, PN and SN changed to 0,0 and $0 \mathrm{mg} / \mathrm{L}$ respectively. Mixed treatment changed the Cr level to nil. So, except Nostoc and Spirodela treatment, all the other methods were highly effective in reducing Cr level of the wastewater.

\section{Effects on Effluent's Color}

The color level was beyond the standard limit in the wastewater sample (1347 TCU) (Table 2). After P, E, N and S treatments, color levels of the effluent were found 1340, 1338, 1345 and 1339 TCU respectively. Color levels in the effluent after the combined treatment of EN, PN and SN were 1223, 1248 and 1230 TCU and mixed treatment was 1216 TCU respectively. So, none of the treatment was able to reduce color effectively from the wastewater.

\section{Heavy Metal Accumulation by Plant}

All the plants used in the present study showed a good affinity towards heavy metals.

From Table 1, it can be inferred, the plants had no or very small amount of heavy metals as fresh and not exposed to the textile wastewater. But, after the exposure, the concentration increased drastically. In fact, Eichhornia, Spirodela and Pistia were biomagnifying the heavy metals by accumulating those in their body and root systems. This tendency makes these aquatic macrophytes suitable for heavy metal removal from the industrial effluents. However, efficiency and tolerance to a particular type of metal is essential for such application. Nevertheless, Eichhormia was found effective in removing most of the heavy metals and showed excellent tolerance against the toxic metals even at high levels. Biological treatment of wastewater is more favorable and cost-effective as compared to other physiochemical methods reported (Metcalf and Eddy, 2003; Haque, 2003).

\section{DISCUSSIONS}

For a sustainable economy, industrial growth is mandatory. In Bangladesh, textile sector is one of the largest industrial sectors fetching majority of the foreign currency and generating bulk of the employment opportunities. So, the socio-economic contribution of the textile industries is undeniable. However, it also produces huge amount of effluent which are very toxic for environment. But, due to the environmental concerns, we cannot step back from the process of industrialization. In this study, attempts were made to characterize the textile wastewater and to treat the effluent with biological means.

The major findings of the study were: i) Physicochemical parameters as TSS, TDS, pH, EC, BOD, COD and color were found to be present higher than the limit, stipulated by WHO, ii) $\mathrm{Pb}, \mathrm{Cu}, \mathrm{As}$, and $\mathrm{Cr}$ was found to be present in much higher concentration than the permissible limit, iii) Water anions (phosphate, sulfate and chloride) were found to be present within the permissible limit, iv) Although Nostoc decreased $\mathrm{Pb}, \mathrm{Cu}$ and Fe level in effluent significantly, yet it has been identified unsuitable for application for textile wastewater treatment as it aggrandized COD, BOD and TSS in the wastewater sample, v) Eichhornia crassipes was found most efficient in reducing TDS, TSS, EC, and COD \& BOD, vi) Mixed treatment was most effective in reducing $\mathrm{pH}$ and among the macrophytes and algae; E. crassipes was most effective in reducing $\mathrm{pH}$, vii) Pistia, Spirodela, Nostoc and Eichhornia, all showed efficacy in removing heavy metals, however, Eichhornia was most effective due to its ability to store higher amount of heavy metals than other macrophytes and algae, viii) None of the macrophytes and algae was able to remove color appreciably from the wastewater, ix) Eichbornia based adsorbent was found to be capable of removing 58\% of color and x) Among the marcophytes (Eichbornia crassipes, Pistia stratiotes and Spirodela polyrbiza) and algae (Nostoc) investigated, Eichhornia crassipes has been identified most expeditious in the treatment of wastewaters from the textile industries.

In previous studies Eichhormia crassipes (Shah et al., 2010; Schneider et al., 1995; Dar et al., 2011), Pistia stratiotes (Rodrigues et al., 2017; Lu et al., 2011) and Spirodela polyrbiza (Ansal et al., 2010; Li et al., 2017) showed their potentials in phytoremediation of wastewater. In a 2017 review article Mishra and Maiti elaborately discussed the previous findings on the pollutant removal characteristics of Eichbornia crassipes (Mishra and Maiti, 2017). E. crassipes previously demonstrated the ability to remove silver from industrial wastewater for subsequent recovery with high efficiency in a short time (Pinto et al., 1987). And also, its rapid growth in polluted wastewater and the capacity to absorb heavy metals (Wolverton and McDonald, 1976). Others observed that E. crassipes have been used 
successfully in wastewater treatment system to improve the water quality by reducing the levels of organic and inorganic nutrients (Brix, 1993; Wolverton and McDonald, 1975). The studied efficacy of Spirodela polyrbiza to remove boron from the contaminated water was reported (Davis, 2007; Davis et al., 2002). COD reduced 69\% from the textile effluent with the combined treatment of Nostoc, Eichhornia crassipes and Pistia stratiotes. With combined treatment of only Nostoc and Eichbornia crassipes, COD reduced 65\% in glass containers (Roy, 2008; Roy et al., 2010). pH reduction from 11.2 to 8.6, showed the algae can reduce textile wastewater metallic contaminants (Shrivastava and Praksh, 1991). And also, can uptake Al, Cu, Ca, Fe, Mg, Mn, and $\mathrm{Zn}$ from dairy manure.

\section{CONCLUSION}

The economy of Bangladesh is galloping due to the rapid progress in the textile industries. Industrial pollution is also a by-product of this achievement. The study showed the potential of macrophytes (Eichhornia crassipes, Pistia stratiotes and Spirodela polyrbiza) and algae (Nostoc) in the treatment of wastewater collected from textile mills. This was a very cheap, convenient process and may be helpful in phytoremediation of industrial wastewater in different sectors and polluted rivers and lakes of Bangladesh.

\section{ACKNOWLEDGEMENT}

The authors are grateful to Mr. Md. Moniruzzaman, SSO, BCSIR Laboratories, Dhaka, for helping to analyze the supplied sample. The authors also express their gratitude to Director, BCSIR Laboratories for useful suggestions and constant encouragement. Also, grateful to staffs from Applied Botany Section, Biological Research Division, for their persistent help and support.

\section{ABBREVIATIONS}

BCSIR: Bangladesh Council of Scientific and Industrial Research; TSS: Total suspended solids; TDS: Total dissolved solids; pH: Negative logarithm of hydrogen ion concentration; EC: Electrical conductivity; DO: Dissolved oxygen; BOD: Biochemical oxygen demand; COD: Chemical oxygen demand; mg/L: Milligram per Liter; ${ }^{\circ} \mathrm{C}$ : Degree centigrade; $\mu \mathrm{S} / \mathrm{cm}$ : Microsiemens per meter; TCU: True color unit; As: Arsenic; Cr: Chromium; $\mathrm{Pb}$ : Lead; Cu: Copper; WHO: World Health Organization; GDP: Gross domestic product; $\mathrm{ZnCl}_{2}$ : Zinc chloride; $\mathrm{NaOH}$ : Sodium hydroxide; Al: Aluminum; Ca: Calcium; Fe: Iron; Mg: Magnesium; Mn: Manganese; Zn: zinc; gm: Gram; Na: Sodium; K: Potassium; $\mathrm{PO}_{4}^{3-:}$ Phosphate; $\mathrm{SO}_{4}{ }^{2-}$ : Sulfate; $\mathrm{Cl}:$ Chloride; $\mathrm{Na}_{2} \mathrm{CO}_{3}$ : Sodium carbonate; $\mathrm{NaHCO}_{3}$ : Sodium bicarbonate; Cd: Cadmium; ppm- Parts per million.

Ethics Approval and Consent to Participate: Not applicable.

Consent for publication: Not applicable.

Data availability: All relevant data are within the paper.

Competing Interests: The authors have declared that no competing interest exists.

Funding: No external funding received.

Authors' Contribution: CKR designed the study and carried out all the experiments, analysis, data interpretations. SSR drafted, edited, finalized, revised the article and coordinated to the publisher. MAAJ participated in designing, supervising and coordinating the study. All authors read and approved the final article.

\section{REFERENCES}

Ahmed, T. (2007). Characterization of textile effluent from selected industries in DEPZ and their treatment by adsorption- filtration process. M. Sc. Thesis, Department of Environmental Sciences, Jahangirnagar University, Saver, Dhaka.

Ansal, M. D., Dhawan, A. and Kaur, V. I. (2010). Duckweed based bio-remediation of village ponds: An ecologically and economically viable integrated approach for rural development through aquaculture. Livest Res Rural Dev., 22(7).

APHA. (1998). Aggregate organic constituents. In Standard method for the examination of water and waste. (A. E. Greenberg, L. S. Clesceri and A. D. Eaton, eds.), 20th (Ed), pp. 513-517. APHA, AWWA \& WEF. 
Azymezyk, M. A., El-Shafei and Freeman, H. S. (2007). Design, synthesis and Characterization of new ironcomplexed azo dyes. Dyes and Pigments, 72(1), 8-15. https://doi.org/10.1016/j.dyepig.2005.07.009

Bangladesh Textile Mills Association (BTMA). (2007). Annual report, pp. 14-35.

Bechtold, T., Mussak, R., Mahmud-Ali, A., Ganglberger, E. and Geissler, S. (2005). Extraction of natural dyes for textile dyeing from coloured plant wastes released from the food and beverage industry. Journal of Science and Food Agriculture, 86, 233-242. https://doi.org/10.1002/jsfa.2360

Brix, H. (1993). Macrophytes -mediated oxygen transfer in wetlands: Transport Mechanism and rate. In: G. A. Moshiri (Ed.), Constructed wetlands for water quality improvement, Ann Arbor, London: Lewis.

Dar, S. H., Kumawat, D. M., Singh, N. and Wani, K. A. (2011). Sewage treatment potential of water hyacinth (Eichhornia crassipes). Research Journal of Environmental Sciences, 5(4), 377. https://doi.org/10.3923/rjes.2011.377.385

Davis, B. (1998). River assessment monitoring project (RAMP) of Kentucky water Watch. Available at: http://water.nr.state.ky.us/ww/ramp/.html (Accessed 20 June 2007)

Davis, S. M., Drake, K. D. and Maier, K. J. (2002). Toxicity of boron to duckweed. Spirodela polyrbiza. Chemosphere, 48, 615-620. https://doi.org/10.1016/S0045-6535(02)00024-3

Deo, H. T. and Desai, B. K. (1999). Dyeing of cotton and jute with tea as a natural dye. Coloration Tech, 115, 224227. https://doi.org/10.1111/j.1478-4408.1999.tb00360.x

Gidhamaari, S., Boominathan and Mamidala, E. (2012). Studies on Efficiency of immobilized bacteria in tannery effluent treatment. Journal of Bio Innovation, 2(2), 33-42.

Gurnham, F. C. (1965). Industrial work control. Academic press, New York.

Hashem, M., Refaie, R. and Hebeish, A. (2005). Crosslinking of partially Carboxymethylated Cotton fabric via cationization. Journal of Cleaner Production, 13, 947-954. https://doi.org/10.1016/j.jclepro.2004.05.002

Haque, M. E. (2003). A compilation of environmental laws of Bangladesh, Administrated by the Department of Environment (DoE).

Kabir, E. S., Kabir, M., Islam, S. M., Mia, C. M., Begum, N., Chowdhury, D. A., Sultana, S. M. and Rahman, S. M. (2002). Assessment of effluent quality of Dhaka export processing Zone with special emphasis to the textile and dying industries. Jahangimagar University Joumal of Science, 25, 137-138.

Karim, M. M., Dasa, A. K. and Lee, S. H. (2006). Treatment of colored effluent of the textile Industry in Bangladesh using zinc chloride treated indigenous activated carbons. Analytica Chimica Acta, 576(1), 37-42. https://doi.org/10.1016/j.aca.2006.01.079

Li, L., Liu, M., Wu, M., Jiang, C., Chen, X., Ma, X., Liu, J., Li, W., Tang, X. and Li, Z. (2017). Effects of duckweed (Spriodela polyrrbiza) remediation on the composition of dissolved organic matter in effluent of scale pig farms. Journal of Environmental Sciences, 55, 247-56. https:// doi.org/10.1016/j.jes.2016.06.033

Lu, Q., He, Z. L., Graetz, D. A., Stoffella, P. J. and Yang, X. (2011). Uptake and distribution of metals by water lettuce (Pistia stratiotes L.). Environmental Science and Pollution Research, 18(6), 978-86. https:// doi.org/10.1007/s11356-011-0453-0

Metcalf and Eddy. (2003). Wastewater Engineering, McGraw Hill Publications. 2. Third Edition, Tata McGrawHill Publishing Company Limited. New Delhi, pp. 16.

Mishra, S. and Maiti, A. (2017). The efficiency of Eichhornia crassipes in the removal of organic and inorganic pollutants from wastewater: a review. Environmental Science and Pollution Research, 1-7. https://doi.org/10.1007/s11356-016-8357-7

Padma, S. V., Rakhi, S., Mahanta, D. and Tiwari, S. C. (2008). Ecofriendly sonicator dyeing of cotton with Rubia cordifolia Linn. using biomordant. Dyes and Pigments, 76(1), 207-212. https:// doi.org/10.1016/j.dyepig.2006.08.023

Pinto, C. L. R., Caconia, A. and Souza, M. M. (1987). Utilization of water hyacinth for removal and recovery of silver from industrial waste water. Water Science and Technology, 19(10), 89-101.

Rajvaiday, N. and Markendey, K. D. (1998). Treatment of textile industrial effluent. Advances in Environmental science and technology, 8, pp. 6, 51-68, 163-172. A. P. H. Publishing Corporation 5, Ansari Road, Darya Ganj, New Delhi110002.

Rodrigues, A. C., do Amaral Sobrinho, N. M., dos Santos, F. S., dos Santos, A. M., Pereira, A. C. and Lima, E. S. (2017). Biosorption of Toxic Metals by Water Lettuce (Pistia stratiotes) Biomass. Water, Air, \& Soil Pollution, 228(4), 156. https://doi.org/10.1007/s11270-017-3340-6

Rott, U. and Minke, R. (1999). Overview of wastewater treatment and recycling in the textile processing industry', Water Science and Technology, 40(1), 37-144. https://doi.org/10.1016/S0273-1223(99)00381-9

Roy, R. (2008). A study of Textile Industrial Effluwnts and Its Treatment Using aquatic Macrophyte and Algae. M.Sc. Thesis, Department of Environmental Sciences, Jahangirnagar University, Saver, Dhaka. 
Roy, R., Fakhruddin, A. N. M., Khatun, R., Islam, M. S., Ahsan, M. A. and Neger, A. J. M. T. (2010). Characterization of Textile Industrial Effluents and its Effects on Aquatic Macrophytes and Algae. Bangladesh J. Sci. Ind. Res, 45(1), 79-84. https://doi.org/10.3329/bjsir.v45i1.5187

Schneider, I. A., Rubio, J., Misra, M. and Smith, R. W. (1995). Eichhornia crassipes as biosorbent for heavy metal ions. Minerals engineering, 8(9), 979-88. https:// doi.org/10.1016/0892-6875(95)00061-T

Sekar, R., Thangaraju, N. and Rengasamy, R. (1995). Effect of seaweed liquid fertilizers form Ulva lactuca on Vigna unguiculata L. (walp.). Phykos, 38, 49-53.

Sekaran, G. and Mariappan, M. (1994). Treatment of salt laden wastewater from tanning industry. Indian Journal of Environmental Protection, 14(11), 801- 806.

Shah, R. A., Kumawat, D. M., Singh, N. and Wani, K. A. (2010). Water hyacinth (Eichhornia crassipes) as a remediation tool for dye effluent pollution. International Journal Science and Nature, 1(2), 172-8.

Shrivastava, P. N. and Praksh, A. (1991). Bio-accumulation of heavy metals by algae and wheat plants fed by textile effluent. Journal of Industrial Pollution Control, 7(1), 25-30.

Slokar, Y. M. and Majcen. M. A. (1997). Methods of decolorization of textile wastewater. Dyes and Pigments, 37(4), 335-356. https:/ /doi.org/10.1016/S0143-7208(97)00075-2

Sultana, M. S., Islam, M. S., Sahaa, R. and Al-Mansur M. A. (2009). Impact of the effluents of textile dying industries on the Surface Water Quality inside D.N.D Embankment, Narayanganj. Bangladesh J. Sci. Ind. Res., 44(1), 65-80. https://doi.org/10.3329/bjsir.v44i1.2715

Tiwari, S., Dixit, S. and Verma, N. (2007). An effective means of bio-filtration of heavy metal contaminated water bodies using aquatic weed Eichhornia crassipes. Environmental Monitoring and Assessment, 129, 153-256. https://doi.org/10.1007/s10661-006-9358-7

Tufekci, N., San, H. A., Aydin, S., Ucar, S. and Barlas, H. (1998). Wastewater Treatment Problems in the Operation of Woven and Knit Fabric Industry. Federation of Europian Biochemical Society, 7, 795-802.

Westhead, K. E., Pizarro, C. and Mulbry, W. W. (2004). Treatment of dairy manure effluent using fresh algae: Elemental composition of algal at different manure loading rates. Journal of Agriculture and Food Chemistry, 52, 7293-7296. https://doi.org/10.1021/jf0491759

WHO. (2002). Water pollutants: Biological agents, Dissolved chemicals, Non dissolved Chemicals, Sediments, Heat. WHO CEHA, Amman, Jordan.

Wolverton, B. C. and McDonald, R. C. (1976). Don't waste water weeds. New Scientists, 318-320.

Wolverton, B. C. and McDonald, R. C. (1975). Water Hyacinth for upgrading sewage lagoon to meet advanced wastewater treatment standards. Part I. NASA TM-X-72729. 